\title{
Inhibiting prolactin by cabergoline accelerates mammary gland remodeling during the early dry period in dairy cows
}

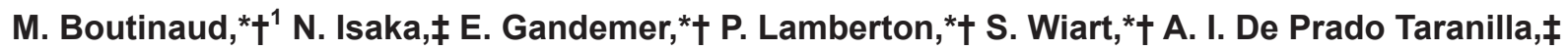 \\ L. M. Sordillo, $§$ and V. Lollivier*†\# \\ *INRA, UMR1348 PEGASE, 35590 Saint-Gilles, France \\ †Agrocampus Ouest, UMR1348 Pegase, F-35000 Rennes, France \\ ‡Ceva Santé Animale, F33500 Libourne, France \\ §Department of Large Animal Clinical Sciences, College of Veterinary Medicine, Michigan State University, East Lansing 48824 \\ \#Université Européenne de Bretagne, F-35000 Rennes, France
}

\begin{abstract}
The inhibition of prolactin release using cabergoline, a dopamine agonist, is an effective strategy to accelerate the changes in mammary secretion composition after drying-off. The objective of this study was to determine how cabergoline may affect mammary tissue remodeling during early involution. Holstein dairy cows were treated with either a single i.m. administration of $5.6 \mathrm{mg}$ of cabergoline (Velactis, Ceva Santé Animale, Libourne, France, $\mathrm{n}=7$ ) or placebo $(\mathrm{n}=7)$ at the time of drying-off. Mammary biopsy samples were collected 1 wk before drying-off $(\mathrm{d}-6)$, after $30 \mathrm{~h}$ of milk accumulation (d 1), and again $8 \mathrm{~d}$ following drying-off (d 8) to determine changes in gene expression, lactoferrin content, and cell turnover. Blood and mammary secretion samples were collected at $\mathrm{d}-6$ and again at d 1, 2, 3, 4, 8, and 14 following the abrupt cessation of lactation to evaluate indicators of blood-milk barrier integrity and other markers of mammary tissue remodeling. Cabergoline induced less $S L C 2 A 1, B A X$, $C A P N 2$, and IGFBP5 mRNA expression. In contrast, cabergoline did not modify changes in cell proliferation and apoptosis. Following the cessation of lactation, changes in mammary secretion composition $\left(\mathrm{Na}^{+}\right.$and $\mathrm{K}^{+}$) and blood lactose concentrations were indicative of a loss in the blood-milk barrier function in both treatment groups. Cabergoline treatment affected only $\mathrm{Na}^{+}$ and $\mathrm{K}^{+}$concentrations at $\mathrm{d} 1$, suggesting a moderate increase in tight junction permeability. The increase in the activity of MMP9 and in mammary epithelial cell concentration in mammary secretions was greater in cabergoline-treated cows than in control cows, suggesting more mammary tissue remodeling. The increase in lactoferrin immunostaining in the mammary tissue oc-
\end{abstract}

Received February 22, 2017.

Accepted August 15, 2017.

${ }^{1}$ Corresponding author: marion.boutinaud@inra.fr curred earlier for cabergoline-treated cows than for control cows, and was essentially localized in the stroma. Changes in some key markers of mammary involution suggest that cabergoline accelerates mammary gland remodeling. Thus, a single injection of cabergoline after the last milking would facilitate drying-off by enhancing mammary gland involution.

Key words: cow, drying-off, prolactin, mammary involution

\section{INTRODUCTION}

The cessation of lactation causes physiological and morphological changes within the bovine mammary gland. The initial phase of the dry period corresponds to not only the cessation of milk synthesis and secretion, but also the onset of tissue remodeling. Intense remodeling of mammary parenchymal tissue is essential for the regeneration of secretory tissue between consecutive lactations that is necessary for optimal milk production (Capuco and Akers, 1999). The speed at which the mammary gland reaches steady-state involution is also essential to optimize the defense mechanisms against mastitis-causing pathogens (Oliver and Sordillo, 1989). Thus, acceleration of mammary gland involution following the abrupt cessation of lactation may not only expedite the tissue remodeling process, but also reduce the susceptibility of the mammary gland to new IMI.

Previous studies identified several biomarkers that can accurately assess the progression of mammary gland involution. The early dry period is characterized by a rapid and intense decrease in the expression of milk protein genes and cell survival genes (Wilde et al., 1997; Singh et al., 2008). The downregulation of genes involved in milk synthesis during early stage of the dry period is a clear indication of the cessation of milk secretion by mammary epithelial cells (MEC). The early nonlactating period is a time of mammary tissue re- 
modeling characterized by significant cellular turnover needed to achieve steady-state involution. Cessation of lactation also is associated with partial loss of the MEC (Wilde et al., 1997). Some MEC die by apoptosis as indicated by the presence of MEC with DNA fragmented nucleus and upregulation of the expression of genes involved in cell death during mammary gland involution (Singh et al., 2008).

The early dry period also is characterized by an increased tight junction permeability that is indicated by the transfer of components between blood and alveolar lumen. Hallmarks of a loss in blood-milk barrier function include in changes of $\mathrm{Na}^{+}$and $\mathrm{K}^{+}$concentrations in mammary secretions (Oliver and Sordillo, 1989) and the presence of lactose in plasma (Stelwagen et al., 1997). Moreover, the increased permeability of tight junctions also facilitates the migration of leukocytes into mammary tissues that participates in the clearance of apoptotic cells and the removal of residual milk components (Atabai et al., 2007). Remodeling of the mammary tissue is also linked with a destruction of the extracellular matrix. During mammary involution, the metalloproteinase (MMP) system is activated and induces the proteolysis of extracellular matrix components (Rabot et al., 2007; Tremblay et al., 2009). An example of extracellular matrix degradation biomarker is the increase in the MMP9 activity in milk analyzed by zymography (Tremblay et al., 2009).

Involution of the mammary gland after the abrupt cessation of milking can be controlled by both local and systemic factors. Accumulated milk within the alveolus is able to induce some remodeling processes due to local factors within the secretory tissues (Tremblay et al., 2009; Weaver and Hernandez, 2016) or due to the increase in the intramammary pressure (Wilde et al., 1999). The cessation of milking, however, also is induced by changes in systemic factors such as the galactopoietic hormones that are released at milking. Milking-induced prolactin (PRL) release, for example, was demonstrated to have a role in regulating MEC activity and turnover (Boutinaud et al., 2012; Lollivier et al., 2015). The inhibition of PRL by quinagolide, a dopamine agonist, was shown to hasten bovine mammary involution (Ollier et al., 2013). Finally, we recently showed that the inhibition of PRL release using cabergoline, another potent dopamine agonist, also is an effective strategy to accelerate mammary involution as suggested by concomitant changes in mammary secretion components (Boutinaud et al., 2016). Thus, inhibiting PRL release at drying-off may accelerate the mammary remodeling process and hasten mammary involution. The present study was carried out to better understand how cabergoline affects mammary tissue involution processes by analyzing key biomarkers that indicate the main mechanisms responsible for secretion cessation and mammary tissue remodeling.

\section{MATERIALS AND METHODS}

\section{Animals and Experimental Design}

All the procedures applied to animals were approved by the Animal Care Committee of the French Ministry of Agriculture and in accordance with French regulations (decree no. 2001-464, May 26, 2001). The study was designed and performed in compliance with the VICH GL9 European Guidelines relating to Good Clinical Practice (EMA, 2000).

Fourteen multiparous Holstein cows $(644 \pm 16.8 \mathrm{~kg}$ of BW) with $323 \pm 21.6$ DIM producing $16.8 \pm 0.91$ $\mathrm{kg}$ of milk at dry-off were randomly assigned to 1 of 2 treatments balanced for milk production, age, BW, lactation rank, pregnancy status, DIM and the 3 last SCC measured at $\mathrm{d}-13,-10$, and -7 . The cows were housed in individual tie-stalls at the INRA Méjusseaume experimental dairy farm, UMR1348 PEGASE (Le Rheu, France). Before drying-off, the cows were milked twice daily at 0730 and $1630 \mathrm{~h}$. All cows were treated with an intramammary antibiotic (Cobactan, Intervet, Beaucouzé, France) after the last milking (at $0730 \mathrm{~h}$ on $\mathrm{d} 0$ ). The cows were surgically equipped with a silastic permanent catheter (Silclear medical-grade silicone tubing, i.d. $1.02 \mathrm{~mm}$, o.d. $2.16 \mathrm{~mm}$; Degania Silicone, Degania Bet, Israel) inserted in the jugular vein the day before the first blood sampling and kept there for the duration of the study.

The treatment consisted of a single aseptic $5 \mathrm{~mL}$ i.m. administration in the neck region of a solution containing $5.6 \mathrm{mg}$ of cabergoline (Velactis, Ceva Santé Animale, Libourne, France; CAB) or an i.m. injection of $5 \mathrm{~mL}$ of the same excipient used in $\mathrm{CAB}$ as a placebo (control) within $4 \mathrm{~h}$ after the last milking before drying-off (d 0 ). The cows were fed according to INRA guidelines as previously described (Boutinaud et al., 2016).

\section{Blood Sample Collection and Analyses}

Blood samples were collected in the morning at 0720 $\mathrm{h}$, before feeding. Blood samples were collected at d $-6,1,2,3,4,8$, and 14 to determine lactose concentrations. Plasma was collected from heparin-coated tubes (Sarstedt, Nümbrecht, Germany) for lactose determination. All plasma samples were separated by centrifugation at $4^{\circ} \mathrm{C}$ and $2,264 \times g$ for $15 \mathrm{~min}$ and then stored at $-20^{\circ} \mathrm{C}$ for subsequent analysis. Plasma concentrations of lactose were measured on a multiparameter analyzer 
(KONE Instruments Corp., Espoo, Finland) with commercial kits (kit for lactose/D-galactose; Roche Diagnostics, Meylan, France).

\section{Mammary Secretion Sample Collection}

Mammary secretion samples were collected at 0730 $\mathrm{h}$ from both front quarters of each cow using a sterilized stainless-steel intraductal cannula $(8 \mathrm{~cm}$, Luer Lock, Clinique Vétérinaire des Falluns, Saint Grégoire, France) that was connected to a plastic tube and gently introduced in the teat sphincter of quarters to collect mammary secretions into a flask. The secretion samples were collected once during lactation $(\mathrm{d}-6)$ and again at d 1, 2, 3, 4, 8, and 14 after drying-off. A total of 290 $\mathrm{mL}$ of mammary secretions was collected from each cow with half of the volume coming from each of their front quarters.

The mammary secretion samples were stored at $-20^{\circ} \mathrm{C}$ for $\mathrm{Na}^{+}$and $\mathrm{K}^{+}$determinations by atomic absorption spectrophotometry (Spectra AA220, Varian, Les Ulis, France) as reported previously (Murthy and Rhea, 1967). Mammary secretion samples also were centrifuged at $1,500 \times g$ for $5 \mathrm{~min}$ at $4^{\circ} \mathrm{C}$ to obtain skimmed mammary secretions that were stored at $-20^{\circ} \mathrm{C}$ for gelatinase activity determinations using zymography as previously described (Yart et al., 2013).

Mammary secretions $(233 \mathrm{~mL}$ ) were used to prepare MEC as previously described (Boutinaud et al., 2008) with some modifications. After milk centrifugation at $1,500 \times g$ for $15 \mathrm{~min}$ at $4^{\circ} \mathrm{C}$, the cell pellet was washed in PBS and suspended in $0.5 \mathrm{~mL}$ of PBS containing $1 \%$ BSA. Each cell sample was incubated with $100 \mu \mathrm{L}$ of a bead/antibody mix prepared for all of the sample and consisting of a $80-\mu \mathrm{L}$ volume of magnetic beads (Pan Mouse IgG, Dynal Biotech, Invitrogen, Cergy Pontoise, France) with $1.6 \mu \mathrm{L}$ of anti-human cytokeratin high molecular weight antibody (M0630, Clone 34ßE12, Dako, Trappes, France). After $1 \mathrm{~h}$ of incubation, the samples were placed in a magnetic particle concentrator (MPC$\mathrm{S}$, Dynal Biotech, Invitrogen) and the supernatant containing nonselected cells was removed. The purified MEC were re-suspended in $0.5 \mathrm{~mL}$ of $1 \%$ PBS-BSA. A $20-\mu \mathrm{L}$ aliquot of purified MEC suspension was collected for cell count and viability determination by a Vi-CELL XR analyzer (Beckman Coulter, Roissy, France).

\section{Mammary Biopsy Sample Collection, Zymography, and Western Blot Analyses}

Mammary biopsy samples were collected at $1330 \mathrm{~h}$ from the upper portion of the mammary gland $1 \mathrm{wk}$ before drying-off $(\mathrm{d}-6)$, and again at $\mathrm{d} 1(30 \mathrm{~h}$ after the last milking) and $\mathrm{d} 8$ using the $70 \times 4 \mathrm{~mm}$ instrument previously described (Farr et al., 1996; Boutinaud et al., 2012) alternating between the left and right hindquarters. The mammary biopsy samples were rinsed in PBS. A portion of the mammary biopsy samples was immediately frozen in liquid nitrogen for RNA, protein, and zymography analysis, and stored at $-80^{\circ} \mathrm{C}$, whereas another portion was fixed in $4 \%$ paraformaldehyde, cryoprotected by incubation for 48 $\mathrm{h}$ in a $40 \%$ sucrose solution, embedded in Tissue-Tek O.C.T. Compound (Sakura Finetek Europe, LaboNord, Templemars, France), frozen in a cooled bath of isopenthane (Sigma-Aldrich), and stored at $-80^{\circ} \mathrm{C}$ until use for immunohistochemistry analysis.

Before zymography, frozen tissues were ground in protein extraction buffer $(50 \mathrm{~m} M$ Tris- $\mathrm{HCl}$ at $\mathrm{pH} 7.5$, $5 \mathrm{mM} \mathrm{CaCl} 2,0.9 \% \mathrm{mM} \mathrm{NaCl}$, and $0.2 \%$ Triton X-100) using an Ultra Turrax homogenizer, sonicated 10 times for $20 \mathrm{~s}$, and incubated on ice for $15 \mathrm{~min}$. After homogenization, the mixture was centrifuged at 13,000 $\times g$ for $15 \mathrm{~min}$ at $4^{\circ} \mathrm{C}$, and the supernatant was recovered. Protein concentration was then determined by the Bradford protein assay (Sigma-Aldrich). Extracted proteins from tissue ( $5 \mu \mathrm{g}$ per lane) or skim mammary secretions were subjected to electrophoresis in $10 \%$ SDS-PAGE as previously described (Yart et al., 2013).

Western blot analyses were performed on mammary tissue as previously described (Ben Chedly et al., 2009) using a 1:2,500 diluted E-cadherin (CDH1) antibody (clone NCH-38, DakoCytomation, Glostrup, Denmark) or a 1:5,000 diluted $\beta$-actin antibody (A5441, Sigma-Aldrich) as primary antibodies and a 1:2,500 diluted horseradish peroxidase conjugated antibody as a secondary antibody (31450, Pierce, Perbio Science, Brebiere, France). Membrane imaging was performed by chemiluminescence with an ImageQuant LAS 4000 imager (GE Healthcare Bio-Sciences AB, Uppsala, Sweden). The integrated optical densities of the bands were quantified using the ImageQuant Tool Lab software (GE Healthcare Bio-Sciences AB). Each sample was normalized by the actin content.

\section{Immunohistochemistry in Mammary Tissue Sections}

The determination of the percentage of apoptotic cells in the mammary gland biopsy sections was based on DNA fragmentation detection using terminal deoxynucleotidyl transferase-mediated dUTP nick-end labeling (TUNEL) staining, as previously described (Boutinaud et al., 2012). Proliferating mammary cells were identified as cells expressing the proliferating cell nuclear antigen (PCNA) as previously described (Boutinaud et al., 2012). To detect lactoferrin, 7- $\mu \mathrm{m}$ cryosections mounted on Superfrost/Plus slides (Prolabo, Bondoufle, France) were thawed and incubated for 
$45 \mathrm{~min}$ in $50 \mathrm{mM}$ amonium chloride (Sigma-Aldrich), washed in $2 \%$ Tris-buffered saline (TBS)-BSA for 1 $\mathrm{h}$, and then incubated for $2.5 \mathrm{~h}$ at room temperature with 1:2,000 diluted rabbit anti bovine lactoferrin serum (gift from V. Rivera, IDBiotech, Issoire, France) in $1 \%$ SDS solution. After 3 washes in $2 \%$ TBS-BSA, the sections were incubated with a 1:400 diluted secondary antibody (Alexa Fluor 488 goat anti-rabbit IgG, SigmaAldrich) for $1 \mathrm{~h}$ at room temperature. Sections were then washed 3 times with 2\% TBS-BSA. Cryosections were permeabilized in TBS with $0.05 \%$ saponin, $2 \%$ BSA, and $0.05 \%$ sodium azide for $1 \mathrm{~h}$ at room temperature and then labeled as previously described in goat mammary tissue (Boutinaud and Jammes, 2004). After TUNEL, PCNA, or lactoferrin labeling, the sections were incubated with 4',6-diamidino-2-phenylindole (DAPI; Sigma-Aldrich), treated and examined under fluorescence as previously described (Boutinaud et al., 2012). After lactoferrin labeling, the outlines of several acini were drawn, and the total lactoferrin staining was measured. For each acinus from the selected part of the slide, the outline of the acinus was drawn and the lactoferrin staining in the acinus was measured, and then the outline of the lumen was drawn in each acinus to measure the lactoferrin content in the lumen. The lactoferrin content in the epithelial compartment was calculated as the difference of staining between acinus and lumen. The lactoferrin content in the stroma was calculated as the difference of staining between total and the sum of acini.

\section{RNA Extraction and Real-Time PCR}

The RNA was extracted with TRIzol (Life Technologies, Saint Aubin, France) from mammary biopsy samples and then purified using the column from the RNeasy Mini Kit (Qiagen, Courtaboeuf, France) according to the manufacturer's recommendations. The RNA pellet was suspended in RNase-free water, and the amount of total RNA was determined with an Agilent 2100 bioanalyzer (Agilent Technologies, Massy, France). The RNA quality was assessed using the RNA integrity number generated by version B.02 of the Agilent 2100 expert software (Agilent Technologies). Total RNA from mammary tissue were used for real-time PCR analyses. Complementary DNA was obtained from $500 \mathrm{ng}$ of total RNA using the First Strand cDNA kit (Promega, Lyon, France) according to the manufacturer's instructions. Real-time PCR was performed using Syber Green Master Mix (Applied Biosystems, Villebon sur Yvette, France) according to the manufacturer's instructions (http://tools.thermofisher.com/content/sfs/manuals/ cms_042179.pdf). The PCR amplifications were performed using the primers for cyclophilin (PPIA), R18S, ribosomal protein large $\mathrm{P} 0(R P L P 0), \alpha$-lactalbumin $(L A L B A)$, k-casein (CSN3), FABP3, glucose transporter 1 (GLUT-1) or solute carrier family 2 member 1 (SLC2A1), $\beta-1,4-N$-acetyl-galactosaminyltransferase 1 (B4GALNT1), fatty acid binding protein 3 (FABP3), E-cadherin (CDH1), occludin $(O C L N)$, collagentype-1 Q-1 (COL1A1), Bax, caspase-3 (CASP3), IGFPB5, calpain-2 (CLPN2), matrix metalloproteinase-2 (MMP2) PRL receptor $(P R L R)$ long isoform, and PRLR short isoform as previously described (Boutinaud et al., 2008, 2012, 2013; Ben Chedly et al., 2009).

The number of amplified mRNA molecules was determined as previously described (Boutinaud et al., 2004). The PPIA, R18S, and RPLPO genes were evaluated as potential reference genes. Bestkeeper (Robinson et al., 2007) and NormFinder (Andersen et al., 2004) programs were used to assess the variability of candidate reference genes. The RPLP 0 and $R 18 S$ were the genes with the most stable expression and the geometric mean between $R P L P 0$ and $R 18 S$ was therefore used as the reference gene. The results for each target gene are expressed as a ratio using the selected reference genes.

\section{Statistical Analyses}

Prerequisites to run each test were checked and data normality was tested with the Shapiro-Wilk test. Thus, PCR data not normally distributed were transformed to decimal logarithms for statistical analysis.

Data were analyzed by ANOVA using the MIXED procedure of the SAS software program (SAS Institute, Cary, NC), and REPEATED statement day was used as a repeated effect, and cow (treatment) was used as the subject. The effects of treatment, cow within treatment, day ( 1 and 8 for variables from biopsies and $\mathrm{d}$ $1,2,3,4,8$, and 14 for the other variables), period, and the treatment $\times$ day interaction were tested as previously reported (Boutinaud et al., 2016). For all variables, the baseline obtained during the pre-treatment period $(\mathrm{d}-6)$ was used as a covariate.

The data concerning the observations before the drying-off were tested for a difference between the 2 groups of animals (CAB and control) using Student's $t$-test. Differences were considered statistically significant when $P \leq 0.05$ and trends were discussed at 0.05 $<P \leq 0.10$.

\section{RESULTS}

\section{Expression of Genes Involved in Milk Synthesis and Cell Death}

The mRNA expression of transcripts involved in milk synthesis (CNS3, LALBA, B4GALNT1, SLC2A1, and 
FABP3) analyzed in the mammary tissue was less at $\mathrm{d}$ 8 than at $\mathrm{d} 1$ and during lactation at $\mathrm{d}-6(P \leq 0.05$, Table 1). The progressive decrease observed during the early dry period for transcripts involved in milk synthesis also was observed for $P R L R$ short isoform mRNA $(P<0.001)$, whereas the long isoform did not vary. In contrast with transcripts involved in milk synthesis, the mRNA abundance of 2 transcripts involved in the regulation of cell death ( $B A X$ and $C A P N 2)$ progressively increased in the mammary tissue after drying-off. Both $B A X$ and $C A P N 2$ mRNA abundance were greater at $\mathrm{d}$ 8 than at $\mathrm{d} 1$ and during lactation at $\mathrm{d}-6(P<0.05)$. An increase between $\mathrm{d} 1$ and 8 was also observed for 2 transcripts involved in mammary remodeling, namely $M M P 2$ and $C O L 1 A 1(P<0.01)$. In contrast, no significant effect of the day after drying-off was observed for transcripts involved in cell death including $C A S P 3$ and IGFBP5 $(P>0.10)$.

No effect of cabergoline was observed on the expression of any $P R L R$ isoform or on the expression of genes involved in milk synthesis, except for $S L C 2 A 1$. Indeed, cabergoline induced less SLC2A1 mRNA expression in the mammary tissue as compared with the control group $(P=0.03$, Table 1$)$. Similarly, cabergoline had significant effects on the expression of 3 genes involved in cell death. When the whole period is considered, the mRNA expression of $B A X, C A P N 2$ and $I G F B P 5$ was less in the cabergoline-treated group than in the control group $(P \leq 0.05)$. This effect or tendency toward an effect is specifically observed at d 1 for CAPN2 $(P=$ $0.01)$ and $B A X(P=0.06)$ and at $\mathrm{d} 8$ for IGFBP5 $(P$ $=0.02)$.

\section{Mammary Epithelial Integrity}

Plasma lactose concentrations increased after dryingoff until d 2 before decreasing between d 4 and $14(P$ $<0.0001$, Figure 1). The concentration of albumin in mammary secretions increased during the first wk after drying-off $(P<0.0001$, Figure 1$)$, then stabilized until $\mathrm{d} 14$. The $\mathrm{Na}^{+}$concentration in mammary secretions increased from drying-off onward, whereas the $\mathrm{K}^{+}$concentration decreased $(P<0.0001$, Figure 1$)$. As a consequence, the $\mathrm{Na}^{+}: \mathrm{K}^{+}$ratio decreased $(P<$ 0.0001 data not shown). No effect of cabergoline was observed on either plasma lactose concentration or albumin concentration in mammary secretions (Figure 1). Moreover, no significant effect of cabergoline was observed on $\mathrm{Na}^{+}$and $\mathrm{K}^{+}$concentration in mammary secretions when the entire trial period was considered $\left(P=0.53\right.$ and $P=0.63$, respectively, for $\mathrm{Na}^{+}$and $\mathrm{K}^{+}$ concentration, Figure 1). Nevertheless, compared with during lactation $(\mathrm{d}-6)$, the rise of $\mathrm{Na}^{+}$concentration in mammary secretions was significant starting at $\mathrm{d} 1$ in the cabergoline-treated cows $(P \leq 0.05)$, but at $\mathrm{d}$ 2 in controls $(P<0.05)$. Moreover, $\mathrm{K}^{+}$concentration

Table 1. $\log _{10}$ of target gene mRNA levels relative to RPLP0 and $R 18 S$ mRNA levels, metalloprotease (MMP) 2 activity, and E-cadherin (CDH1) protein level in mammary tissue collected by biopsy during lactation at d -6 (baseline) and after drying-off (d 1 and 8 ) in dairy cows injected with cabergoline (CAB, $5.6 \mathrm{mg}$, injected i.m.; $\mathrm{n}=7$ ) or vehicle (control; $\mathrm{n}=7)^{1}$

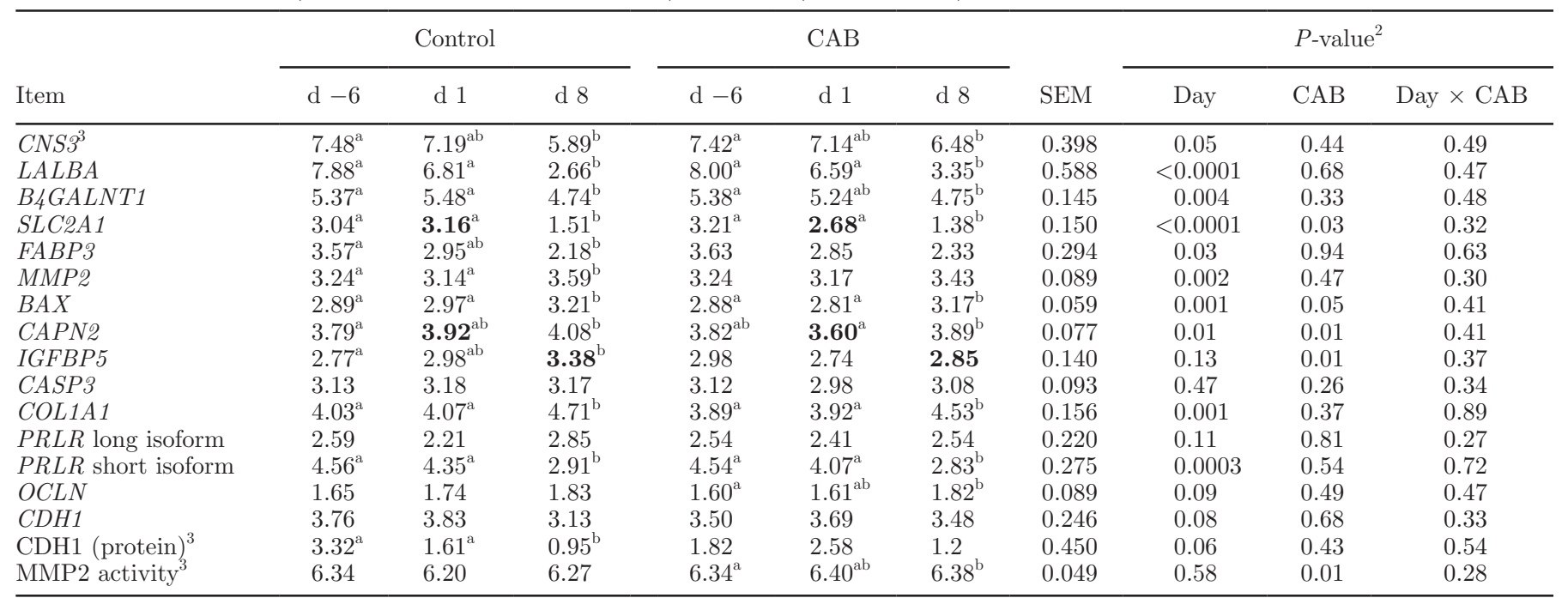

\footnotetext{
${ }^{\mathrm{a}, \mathrm{b}}$ Different superscript letters indicate a significant difference compared with $\mathrm{d}-6$ and between $\mathrm{d} 1$ and 8 for each group of cows. ${ }^{1}$ Data are presented as LSM \pm SEM. Values in bold indicate a significant difference according to the treatments at a specific day.

${ }^{2}$ Statistical analyses took into account the effects of day, CAB, and the interaction of day $\times$ CAB.

${ }^{3}$ Analyses were performed on the semi-absolute mRNA molecule number relative to RPLP0 and R18S and multiplied by $10^{7}$ and $\log _{10}$-transformed. The CDH1 protein is expressed with an arbitrary unit, a ratio of gray intensity after $\beta$-actin normalization, and MMP2 activity as a $\log$ of gray intensity.
} 
tended to be less in cabergoline-treated group than in the control group on d $1(P=0.06$, Figure 1$)$.

No effect of cabergoline was observed after dryingoff for both E-cadherin mRNA and protein and OCLN mRNA expression in mammary tissue.

\section{Metalloproteinase Activities}

The MMP activities of MMP9 and MMP2 progressively increased from $\mathrm{d} 1$ to 14 in mammary secretions $(P<0.001$, Figure 2$)$. The MMP9 activity is at the maximum at $\mathrm{d} 8$ after drying-off. In the mammary tissue, MMP2 and MMP9 activities did not change between $\mathrm{d} 1$ and $8(P=0.57$, Table 1 for MMP2; data not shown for MMP9).

Cabergoline had significant effects on specific MMP activities in both types of samples. In mammary secretions, MMP9 activity was significantly greater in the cabergoline-treated group than in control group over the entire trial period $(P=0.03$, Figure 2$)$. The stimulating effect of cabergoline on MMP9 activity in mammary secretions was particularly significant on d $1(P=$ $0.04)$ and $\mathrm{d} 2(P=0.005)$. In contrast, cabergoline did not affect MMP2 activity in mammary secretions (Figure $2 \mathrm{~A}$ ). In mammary tissue, cabergoline increased the activity of MMP2 $(P=0.01$, Table 1$)$ but not MMP9 after drying-off (data not shown).

\section{Concentrations of Lacteal MEC}

The concentration of MEC in mammary secretions progressively increased with the day after drying-off ( $P$ $=0.001$, Figure 1$)$. In contrast, the viability of MEC in mammary secretions did not vary according to the day after drying-off $(P=0.87)$. Cabergoline had a significant effect on the concentration of MEC in mammary secretions, showing greater concentration in cabergoline-treated group than in the control group $(P=0.04)$. For the control group, MEC concentration was greater at $\mathrm{d} 8$ than during lactation $(P<0.05)$, whereas for the cabergoline-treated group, this happened at d 14 (data not shown). When the entire period is considered, cabergoline did not affect the viability of MEC in mammary secretions. However, MEC viability was significantly less in the cabergoline-treated group than in control group on d $4(P=0.02$, Figure 1$)$.

\section{Immunohistological Analyses of Mammary Cell Turnover and Lactoferrin Staining}

The percentage of PCNA positive cells in the mammary tissue was less at $\mathrm{d} 1$ than during lactation in both groups of cows (Table 2). Thereafter, the percentage of PCNA-positive cells increased between $\mathrm{d} 1$ and 8 of drying-off $(P=0.002)$. In contrast, the percentage of apoptotic cells was greater at $\mathrm{d} 1$ than during lactation in both groups of cows. The percentage of apoptotic cells did not vary significantly between $\mathrm{d} 1$ and 8 of drying-off $(P=0.13)$. Cabergoline did not affect either the percentage of PCNA-positive cells or the percentage of apoptotic cells in the mammary tissue.

An increase in the total mammary tissue area positive for lactoferrin immunostaining was observed at $\mathrm{d} 1$ for the cabergoline-treated cows and at $\mathrm{d} 8$ for control cows compared with during lactation $(P<0.05$ Table 2 and Figure 3). An interaction between day and cabergoline treatment was observed $(P=0.001)$. Lactoferrin immunostaining in the cabergoline-treated group had a tendency to decrease between d 1 and $8(P=0.09)$, but increased in the control group $(P=0.02)$. After drying-off, the increase in lactoferrin immunostaining is essentially due to an increase in lactoferrin content in the stroma and in the lumen without significant modification in the epithelium (Figure 3). The increase in lactoferrin staining in the stroma was observed between $\mathrm{d}-6$ and 1 for cabergoline-treated cows and between $\mathrm{d}$ 1 and 8 for controls cows.

The size of the acini was studied by immunohistological analyses with 2 criteria, the acinus area and the acinus diameter (Table 2). In the control group, acinus area was less at $\mathrm{d} 8$ than during lactation at $\mathrm{d}-6(P=$ 0.01 ), but did not vary in the cabergoline-treated group. During drying-off, acinus area was not significantly affected by the day after drying-off and cabergoline treatment. Acinus diameter in the control group did not vary at $\mathrm{d}-6,1$, or 8 , but the cabergoline-treated group had greater acinus diameter at d 8 when compared with $\mathrm{d}-6(P<0.05)$. Greater acinus diameter was observed in cabergoline-treated group than in control group at d $8(P=0.02)$. The proportion of acinus, epithelium, and stroma in the mammary tissue did not vary following drying-off or with cabergoline treatment (Table 2). A significant increase was observed in the area of tissue occupied by lumen with the day after drying-off $(P=$ $0.005)$ and at $\mathrm{d} 8$ for both treatment groups $(P<0.05)$. Interestingly, the histological analyses showed some MEC shedding into the alveolar lumen, but only after $8 \mathrm{~d}$ in the cabergoline-treated cows (data not shown).

\section{DISCUSSION}

The present study was carried out to better understand how cabergoline affects mammary tissue remodeling. 

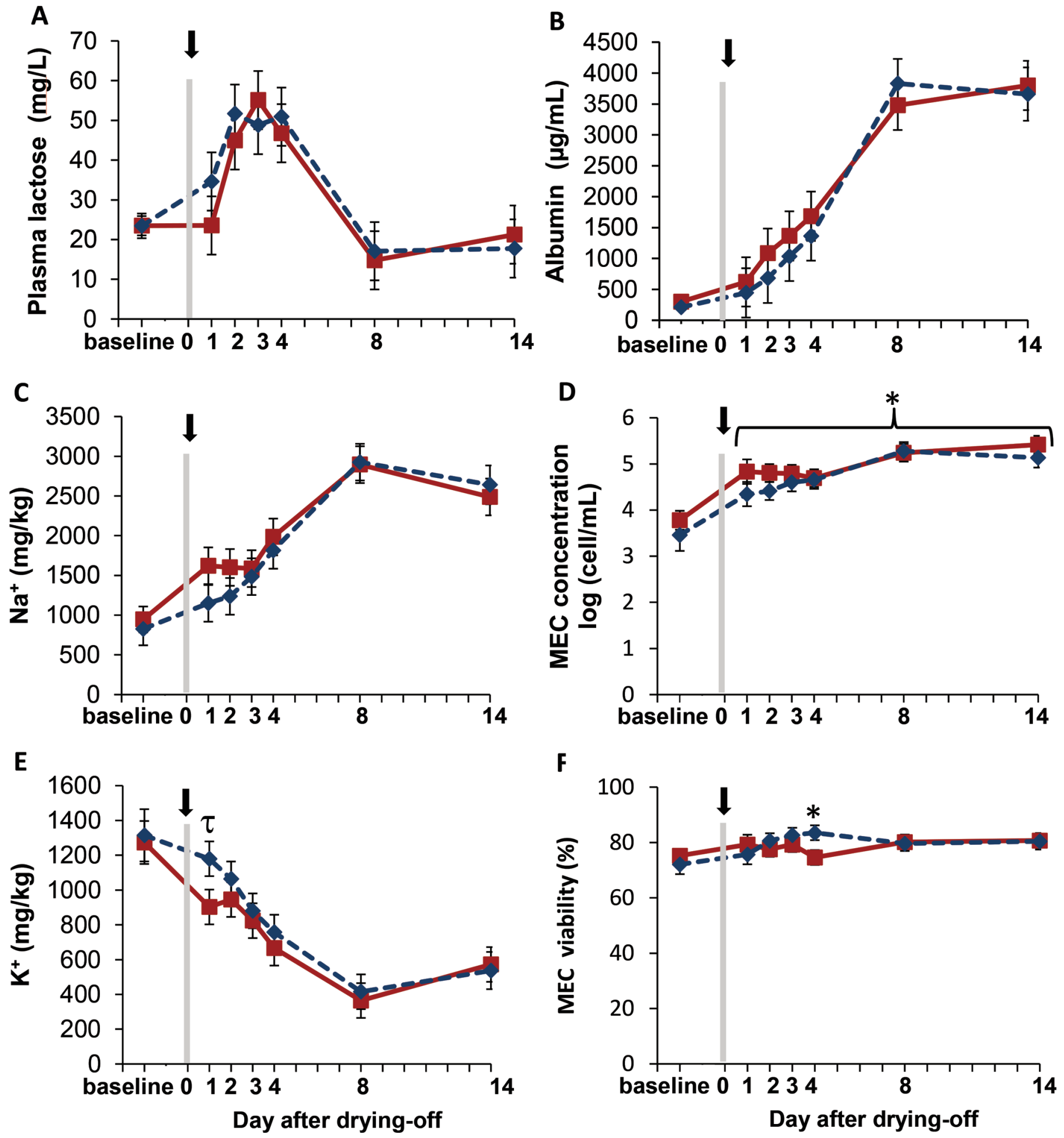

Figure 1. Concentrations of plasma lactose (A), albumin (B), sodium (B), potassium (E), and mammary epithelial cells (MEC; D) and MEC viability $(\mathrm{F})$ in mammary secretions collected before morning milking at $\mathrm{d}-6$ (baseline) and after drying-off (d $1,2,3,4,8$, and 14$)$ in dairy cows injected (arrow) with the cabergoline $(\mathrm{CAB}, 5.6 \mathrm{mg}$, injected i.m.; $\mathrm{n}=7$; $\mathbf{0}$ ) or vehicle (control; $\mathrm{n}=7 ; \boldsymbol{\bullet}$ ) at d 0 of drying-off (gray bar). Data are presented as LSM \pm SEM. ${ }^{*} P<0.05, \tau P<0.10$. The statistical probabilities were tested by ANOVA using a MIXED procedure showing the effects of day $(P<0.001)$, cabergoline $(\mathrm{NS})$, and day $\times$ cabergoline $(\mathrm{NS})$ except for MEC concentration where a cabergoline effect $(P=0.04)$ and for MEC viability where no effects of day were observed. Color version available online. 


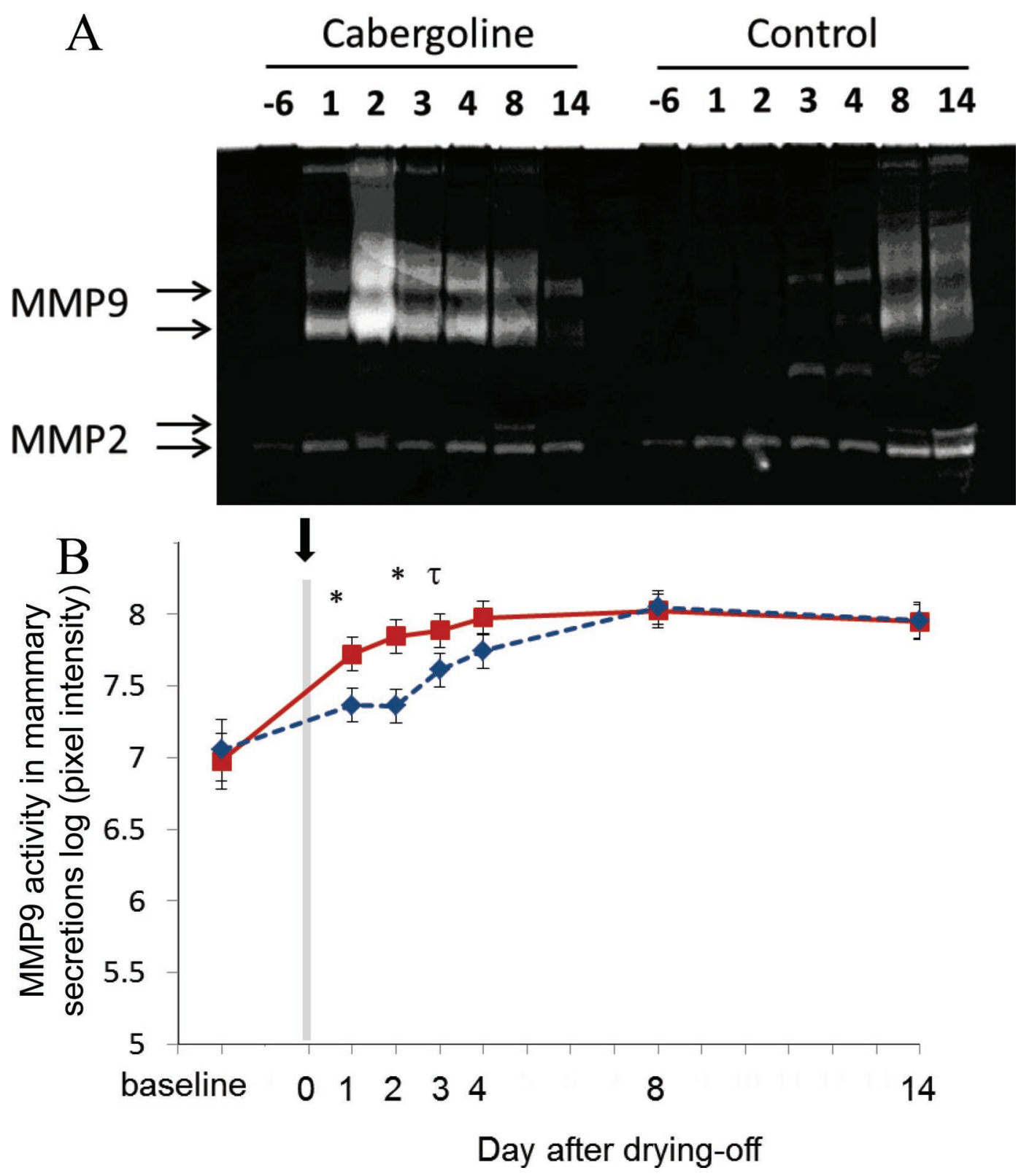

Figure 2. Metalloprotease (MMP) 9 and MMP2 activities in mammary secretions collected before morning milking at d -6 (baseline) and after drying-off ( $\mathrm{d} 1,2,3,4,8$, and 14) in dairy cows injected (arrow) with cabergoline (5.6 mg, injected i.m.; $\mathrm{n}=7 ; \boldsymbol{\square})$ or the vehicle (control; $\mathrm{n}=7$; ) at d 0 of the drying-off (gray bar). (A) Analysis of MMP9 and MMP2 protein activity using the gelatin zymography in mammary secretion from representative injected and control cows. (B) Graphical representation of MMP9 protein activity. Activities were quantified by densito-metrically scanning the photographic negative of the zymogram and were expressed as the $\log _{10}$ of pixel intensity. Data are presented as $\mathrm{LSM} \pm$ SEM. $* P<0.05, \tau P<0.10$. The statistical probabilities were tested by ANOVA using a MIXED procedure showing the effects of day $(P<0.0001)$, cabergoline $(P=0.03)$, and day $\times$ cabergoline $(P=0.16)$. Color version available online.

\section{Early Dry Period and Key Biomarkers of Mammary Involution}

The decrease in expression of genes involved milk synthesis (i.e., LALBA, CSN3, B4GALNT1, SLC2A1, and $F A B P 3)$ clearly indicated a progressive milk secretion cessation during the early dry period, which is consistent with previous reports (Camps et al., 1994;
Singh et al., 2008). The remodeling of mammary tissue is partly the result of apoptosis and proliferation and is characterized by a phase of tissue regression followed by a regeneration phase (Atabai et al., 2007). The expression of genes involved in mammary cell death (BAX and CAPN2) in the present study was related to an increase in the percentage of apoptotic cells in mammary tissue as previously observed (Singh et al., 2005; 


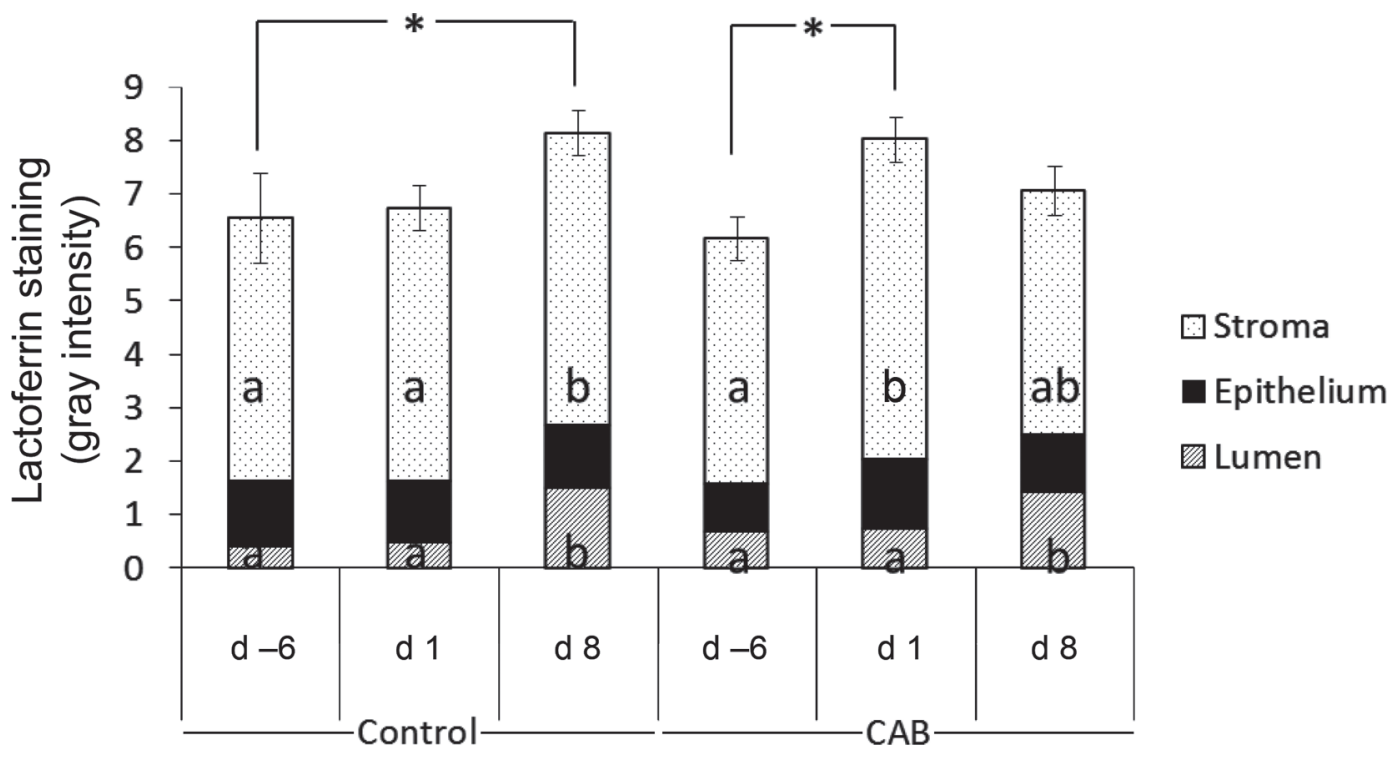

Figure 3. Lactoferrin localization into mammary structures (stroma, epithelium, and lumen) from dairy cows injected with the cabergoline $(\mathrm{CAB}, 5.6 \mathrm{mg}$, injected i.m.; $\mathrm{n}=7$ ) or vehicle (control; $\mathrm{n}=7$ ). The mammary tissue sections from the CAB and control collected during lactation at $\mathrm{d}-6$ and after drying-off at $\mathrm{d} 1$ and 8 were stained simultaneously with 4',6-diamidino-2-phenylindole (DAPI) and lactoferrin antiserum. Graphical representation of lactoferrin localization. Lactoferrin staining was expressed as the pixel intensity in each mammary structure. Data are presented as LSM \pm SEM. ${ }^{*} P<0.05$; a,b for $P<0.05$. The statistical probabilities were tested by ANOVA using the MIXED procedure. The effects for lactoferrin staining were analyzed for each mammary tissue compartment and were as follows: in the stroma, day $(P=0.06)$, cabergoline $(P=0.97)$, and day $\times$ cabergoline $(P=0.01)$; in the epithelium, day $(P=0.28)$, cabergoline $(P=0.83)$, and day $\times$ cabergoline $(P$ $=0.19)$; and in the lumen, day $(P=0.0001)$, cabergoline $(P=0.59)$, and day $\times$ cabergoline $(P=0.07)$.

Sorensen et al., 2006). Cellular proliferation decreased in by the first day of the dry period and thereafter, apoptosis rates remained high, whereas proliferation increased, showing a clear alteration of cell turnover allowing the regression of the mammary tissue.

Activation of the MMP system is involved in the remodeling of the extracellular matrix during mammary gland involution (Rabot et al., 2007; Tremblay et al., 2009; Ponchon et al., 2014). Increases in MMP2 and
COL1A1 mRNA abundance in mammary tissue and in MMP2 and MMP9 activities in mammary secretions indicated a greater potential proteolysis of the mammary extracellular matrix components during the early phase of the dry period. This activation of MMP system could result in induction of apoptosis ( $\mathrm{Li}$ et al., 2016), suppression of survival factors provided by the extracellular matrix, or the early degradation of the blood-milk barrier (Raulo et al., 2002).

Table 2. Immunohistological analyses (cell proliferation and apoptosis, total lactoferrin staining, acinus area and diameter, and the percentages of tissue area occupied by acini, lumen, epithelium, and stroma) in mammary tissue collected by biopsy during lactation at $\mathrm{d}-6$ (baseline) and after drying-off ( $\mathrm{d} 1$ and 8) in dairy cows injected with the cabergoline $(\mathrm{CAB}, 5.6 \mathrm{mg}$, injected i.m.; $\mathrm{n}=7)$ or vehicle $(\text { control; } \mathrm{n}=7)^{1}$

\begin{tabular}{|c|c|c|c|c|c|c|c|c|c|c|}
\hline \multirow[b]{2}{*}{ Item } & \multicolumn{3}{|c|}{ Control } & \multicolumn{3}{|c|}{$\mathrm{CAB}$} & \multirow[b]{2}{*}{ SEM } & \multicolumn{3}{|c|}{$P$-value ${ }^{2}$} \\
\hline & $\mathrm{d}-6$ & d 1 & d 8 & $\mathrm{~d}-6$ & d 1 & d 8 & & Day & $\mathrm{CAB}$ & Day $\times$ CAB \\
\hline Proliferation (\%) & $16.9^{\mathrm{a}}$ & $9.9^{\mathrm{b}}$ & $12.7^{\mathrm{ab}}$ & $18.5^{\mathrm{a}}$ & $7.1^{\mathrm{b}}$ & $12.4^{\mathrm{a}}$ & 3.09 & 0.002 & 0.32 & 0.15 \\
\hline Apoptosis (\%) & $0.22^{\mathrm{a}}$ & $0.47^{\mathrm{b}}$ & $0.59^{\mathrm{b}}$ & $0.27^{\mathrm{a}}$ & $0.49^{\mathrm{b}}$ & $0.35^{\mathrm{ab}}$ & 0.083 & 0.61 & 0.13 & 0.21 \\
\hline Total staining of lactoferrin ${ }^{3}$ & $6.54^{\mathrm{a}}$ & $6.69^{\mathrm{ab}}$ & $8.16^{\mathrm{b}}$ & $6.16^{\mathrm{a}}$ & $8.00^{\mathrm{b}}$ & $7.04^{\mathrm{ab}}$ & 0.83 & 0.39 & 0.87 & 0.001 \\
\hline Acinus area $\left(10^{3} \mu \mathrm{m}^{2}\right)$ & 12.02 & 11.53 & 10.28 & 10.99 & 11.47 & 13.14 & 1.44 & 0.80 & 0.27 & 0.10 \\
\hline Acinus diameter $(\mu \mathrm{m})$ & 94.7 & 89.3 & 82.6 & $87.3^{\mathrm{a}}$ & $89.4^{\mathrm{a}}$ & $97.4^{\mathrm{b}}$ & 5.2 & 0.86 & 0.08 & 0.06 \\
\hline Acini $(\%)$ & 35 & 35 & 35 & 33 & 37 & 33 & 1.7 & 0.12 & 0.51 & 0.84 \\
\hline Lumen (\%) & $10^{\mathrm{a}}$ & $10^{\mathrm{a}}$ & $12^{\mathrm{b}}$ & $10^{\mathrm{a}}$ & $10^{\mathrm{a}}$ & $13^{\mathrm{b}}$ & 1.0 & 0.005 & 0.69 & 0.65 \\
\hline Epithelium (\%) & 25 & 23 & 23 & 23 & 25 & 24 & 1.2 & 0.23 & 0.56 & 0.38 \\
\hline Stroma $(\%)$ & 65 & 67 & 65 & 67 & 65 & 63 & 1.7 & 0.12 & 0.51 & 0.84 \\
\hline
\end{tabular}

\footnotetext{
${ }^{\mathrm{a}, \mathrm{b}}$ Different superscript letters indicate a significant difference compared with $\mathrm{d}-6$ and between $\mathrm{d} 1$ and 8 for each group of cows.

${ }^{1}$ Data are presented as LSM \pm SEM. Values in bold indicate a significant difference according to the treatments at a specific day.

${ }^{2}$ Statistical analyses took into account the effects of day, CAB, and the interaction of day $\times \mathrm{CAB}$.

${ }^{3}$ Total staining of lactoferrin was expressed as the pixel intensity in one micrograph picture.
} 
Another characteristic of the progress of mammary involution is the disruption of the mammary epithelial integrity. In accordance with previous studies (Stelwagen et al., 1997; Ben Chedly et al., 2009; Ponchon et al., 2014), increased $\mathrm{Na}^{+}: \mathrm{K}^{+}$ratio in mammary secretions with a concomitant increase in lactose concentrations in plasma clearly showed the increased permeability of tight junctions during the early dry period. The disruption of the mammary epithelial integrity may have facilitated the massive migration of leukocytes previously observed during the early phase of the dry period (Boutinaud et al., 2016). The disruption of mammary epithelial integrity was accompanied by an increase in MEC concentration in mammary secretions, suggesting an enhancement of MEC shedding from the alveolar structure. Increased MEC shedding with a concomitant disruption of mammary epithelial integrity was reported previously during lactation (Herve et al., 2016). In the mouse mammary gland, numerous MEC are rapidly observed in alveolar lumen within 24 h until $4 \mathrm{~d}$ of mammary involution (Monks and Henson, 2009; Watson and Kreuzaler, 2011). In bovine mammary glands, this phenomenon seems to happen later (after $8 \mathrm{~d}$ in the control group) and is less intense since it can be observed in mammary secretions, but barely on histology examination (Holst et al., 1987) as in our immunohistological micrographs. The MEC shedding at $\mathrm{d} 8$ is probably made possible by the remodeling of the extracellular matrix that happened very early during the dry period. Only a moderate degree of tissue remodeling was shown compared with that observed in involuting mouse mammary glands. Involution of bovine mammary tissues only caused an increase in the percentage of area occupied by the lumen between $\mathrm{d} 1$ and 8 as previously observed in a later stage of involution (Capuco et al., 1997) with no other changes in the general architecture of the mammary tissue. Nevertheless, the progress of involution in our study is consistent with what was reported in the literature concerning remodeling of bovine mammary tissues following the cessation of milk secretion.

\section{Effects of Cabergoline Treatment on Mammary Involution}

A previous study showed that the PRL inhibitor, cabergoline, accelerated mammary involution as reflected by changes in mammary secretion composition (Boutinaud et al., 2016). Although it did not affect mammary tissue expression of most genes involved in milk synthesis, cabergoline clearly induced a downregulation of SLC2A1 mRNA coding for the main glucose transporter in the MEC and that could be responsible for less glucose availability for lactose synthesis. Indeed, less lactose concentration was previously observed in mammary secretions of cabergoline-treated cows (Boutinaud et al., 2016). Our results differ from those observed in lactating rats (Camps et al., 1994) or in dairy cows (Boutinaud et al., 2012) that showed no effect on SLC2A1 mRNA abundance when PRL was inhibited by bromocriptine or quinagolide. However, cabergoline is a stronger dopamine agonist than either quinagolide or bromocriptine, and thus, cabergoline may more likely affect glucose transport in MEC than the other dopamine agonists. Because lactose is the main osmotic agent in the milk, the downregulation of SLC2A1 mRNA could be one of the factors responsible for less udder engorgement and milk leakage observed in cows treated with cabergoline (Bach et al., 2015; Bertulat et al., 2017).

Although drying-off affected cell turnover in the mammary gland, cabergoline did not alter cell proliferation and cell death. In contrast, cabergoline treatment downregulated mRNA expression of genes involved in cell death ( $B A X$ and $C A P N 2)$ that are normally upregulated in mammary tissue following dry-off. These findings were unexpected because PRL is known to have a survival effect in mammary tissue (Boutinaud et al., 2012; Lollivier et al., 2015). Further research is needed to investigate if the effect of cabergoline on cell death could be due to sampling time or to more efficient removal of dead cells by enhanced milk SCC (Boutinaud et al., 2016).

Prolactin was previously shown to reduce the permeability of the paracellular pathway (Linzell et al., 1975) and thus, increase mammary epithelial integrity. The accelerated rise of $\mathrm{Na}^{+}$concentration and the tendency toward less $\mathrm{K}^{+}$concentration in mammary secretions at $d 1$ in the cabergoline-treated cows suggested that cabergoline may have amplified and accelerated the opening of tight junctions on the first day of the dry period. However, blood lactose is another marker of tight junction integrity that was not affected by cabergoline. Thus, cabergoline seems to moderately amplify and accelerate the opening of tight junctions. This effect could be due to reduced milk secretion after cabergoline treatment as indicated by a reduced udder pressure and firmness as well as milk leakage previously reported (Bach et al., 2015; Bertulat et al., 2017). However, further studies have to be performed to confirm this hypothesis.

Cabergoline amplified and accelerated the increase in MMP9 activity in mammary secretions and increased MMP2 activity in mammary tissue. Therefore, cabergoline treatment appears to have increased the remodeling of the extracellular matrix via MMP activity induction. These effects are consistent with a tendency toward an increase in MMP2 activities in cows treated 
with quinagolide at drying-off (Ollier et al., 2013). This effect could either be the cause or the consequence of the greater mammary infiltration of immune cells in cabergoline-treated cows (Boutinaud et al., 2016). Indeed, PRL can inhibit the synthesis of MMP9 by leukocytes (Yu et al., 2011) or MMP2 and MMP9 by MEC (Lee et al., 2001). Thus, in association with the opening of tight junctions, the more intense and accelerated extracellular matrix remodeling could allow the enhancement of SCC in mammary secretions. The increase in MEC concentrations in cabergoline-treated cows could be the consequence of a more intense mammary tissue remodeling because it occurred after the enhancement of tight junction disruption and extracellular matrix degradation. Collectively, these findings suggest that MEC become exfoliated when they lose contact with survival factors contained in the extracellular matrix as previously shown by others (Katz and Streuli, 2007). Thus, a single treatment with cabergoline can achieve similar effects on MMP2-mediated activities and MEC exfoliation as several treatments with quinagolide (Ollier et al., 2013; Lollivier et al., 2015).

Drying-off is a period of risk of new IMI (Smith et al., 1985). An important component of the mammary immune system is the presence of the antimicrobial protein, lactoferrin. An accelerated and enhanced increase in lactoferrin concentration in mammary secretions previously was observed after cabergoline treatment at drying-off (Boutinaud et al., 2016). We confirmed the increase in lactoferrin content within mammary tissues during the early dry period, especially within stroma and lumen areas. The mammary content of lactoferrin increased earlier in the nonlactating period for cabergoline-treated cows when compared with the control group. The ability of cabergoline treatment to cause a more rapid accumulation of lactoferrin in mammary tissues might hasten the antibacterial defenses when cows are especially susceptible to new IMI.

\section{CONCLUSIONS}

This study confirms the acceleration of mammary involution after cabergoline treatment, a dopamine agonist that inhibits PRL release. Although cabergoline treatment only slightly accelerated the tight junction opening and caused modest modifications in expression of some genes, it did enhance the remodeling of the extracellular matrix during early involution. This study is the first that reports a massive exfoliation of MEC into mammary secretions after drying-off that may be a consequence of remodeling of the extracellular matrix. Because cabergoline enhanced MEC exfoliation and MMP2 and MMP9 activities, this suggests a greater degree of mammary tissue remodeling following treat- ment with this PRL secretion inhibitor. Moreover, we confirmed the acceleration of lactoferrin content in mammary tissues after cabergoline treatment, suggesting a better capacity to resist new IMI during mammary gland involution. Cabergoline treatment might contribute to improve the health and welfare of dairy cows at the time of dry-off by enhancing mammary tissue remodeling processes.

\section{ACKNOWLEDGMENTS}

The authors thank the team of the experimental farm (INRA, Le Rheu, France), for taking care of the cows and their assistance with milk, plasma, and mammary secretion sampling. We are also grateful to S. Marion, L. Finot, S. Wiart, A. Gillard, E. Le Guennec, A. Emo, C. Mustière, P. Debournoux, and T. Le Mouël (INRA, Saint Gilles, France) for their technical help and to J. Bertet (Ceva Santé Animale, Libourne, France) for assistance with monitoring the data. The authors thank V. Rivera (IDBiotech, Issoire, France) for the kind gift of the rabbit anti-bovine lactoferrin serum. The authors are grateful to Ceva Santé Animale (Libourne, France) and INRA for providing funding to conduct this study.

\section{REFERENCES}

Andersen, C. L., J. L. Jensen, and T. F. Orntoft. 2004. Normalization of real-time quantitative reverse transcription-PCR data: A model-based variance estimation approach to identify genes suited for normalization, applied to bladder and colon cancer data sets. Cancer Res. 64:5245-5250.

Atabai, K., D. Sheppard, and Z. Werb. 2007. Roles of the innate immune system in mammary gland remodeling during involution. J. Mammary Gland Biol. Neoplasia 12:37-45.

Bach, A., A. De-Prado, and A. Aris. 2015. Short communication: The effects of cabergoline administration at dry-off of lactating cows on udder engorgement, milk leakages, and lying behavior. J. Dairy Sci. 98:7097-7101.

Ben Chedly, H., P. Lacasse, P. G. Marnet, S. Wiart-Letort, L. Finot, and M. Boutinaud. 2009. Cell junction disruption after $36 \mathrm{~h}$ milk accumulation was associated with changes in mammary secretory tissue activity and dynamics in lactating dairy goats. J. Physiol. Pharmacol. 60(Suppl. 3):105-111.

Bertulat, S., N. Isaka, A. de Prado, A. Lopez, T. Hetreau, and W. Heuwieser. 2017. Effect of a single injection of cabergoline at dry off on udder characteristics in high-yielding dairy cows. J. Dairy Sci. 100:3220-3232.

Boutinaud, M., M. H. Ben Chedly, E. Delamaire, and J. GuinardFlament. 2008. Milking and feed restriction regulate transcripts of mammary epithelial cells purified from milk. J. Dairy Sci. 91:988998.

Boutinaud, M., L. Galio, V. Lollivier, L. Finot, S. Wiart, D. Esquerre, and E. Devinoy. 2013. Unilateral once daily milking locally induces differential gene expression in both mammary tissue and milk epithelial cells revealing mammary remodeling. Physiol. Genomics 45:973-985.

Boutinaud, M., N. Isaka, V. Lollivier, F. Dessauge, E. Gandemer, P. Lamberton, A. I. Taranilla, A. Deflandre, and L. M. Sordillo. 2016. Cabergoline inhibits prolactin secretion and accelerates involution in dairy cows after dry-off. J. Dairy Sci. 99:5707-5718.

Boutinaud, M., and H. N. Jammes. 2004. Growth hormone increases Stat5 and Stat1 expression in lactating goat mammary gland: A 
specific effect compared to milking frequency. Domest. Anim. Endocrinol. 27:363-378.

Boutinaud, M., V. Lollivier, L. Finot, R. M. Bruckmaier, and P. Lacasse. 2012. Mammary cell activity and turnover in dairy cows treated with the prolactin-release inhibitor quinagolide and milked once daily. J. Dairy Sci. 95:177-187.

Boutinaud, M., J. H. Shand, M. A. Park, K. Phillips, J. Beattie, D. J. Flint, and G. J. Allan. 2004. A quantitative RT-PCR study of the mNA expression profile of the IGF axis during mammary gland development. J. Mol. Endocrinol. 33:195-207.

Camps, M., S. Vilaro, X. Testar, M. Palacin, and A. Zorzano. 1994 High and polarized expression of GLUT1 glucose transporters in epithelial cells from mammary gland: Acute down-regulation of GLUT1 carriers by weaning. Endocrinology 134:924-934.

Capuco, A. V., and R. M. Akers. 1999. Mammary involution in dairy animals. J. Mammary Gland Biol. Neoplasia 4:137-144.

Capuco, A. V., R. M. Akers, and J. J. Smith. 1997. Mammary growth in Holstein cows during the dry period: Quantification of nucleic acids and histology. J. Dairy Sci. 80:477-487.

European Agency for the Evaluation of Medicinal Products (EMA) 2000. Guideline on clinical good practice. Accessed Sep. 15, 2017. http://www.ema.europa.eu/docs/en_GB/document_library/ Scientific_guideline/2009/10/WC500004343.pdf.

Farr, V. C., K. Stelwagen, L. R. Cate, A. J. Molenaar, T. B. McFadden, and S. R. Davis. 1996. An improved method for the routine biopsy of bovine mammary tissue. J. Dairy Sci. 79:543-549.

Herve, L., H. Quesnel, V. Lollivier, and M. Boutinaud. 2016. Regulation of cell number in the mammary gland by controlling the exfoliation process in milk in ruminants. J. Dairy Sci. 99:854-863.

Holst, B. D., W. L. Hurley, and D. R. Nelson. 1987. Involution of the bovine mammary gland: Histological and ultrastructural changes. J. Dairy Sci. 70:935-944.

Katz, E., and C. H. Streuli. 2007. The extracellular matrix as an adhesion checkpoint for mammary epithelial function. Int. J. Biochem. Cell Biol. 39:715-726.

Lee, P. P. H., J. J. Hwang, L. Mead, and M. M. Ip. 2001. Functional role of matrix metalloproteinases (MMPs) in mammary epithelial cell development. J. Cell. Physiol. 188:75-88.

Li, H., H. Zheng, L. Li, X. Shen, W. Zang, and Y. Sun. 2016. The effects of matrix metalloproteinase-9 on dairy goat mastitis and cell survival of goat mammary epithelial cells. PLoS One 11:e0160989.

Linzell, J. L., M. Peaker, and J. C. Taylor. 1975. Effects of prolactin and oxytocin on milk secretion and on permeability of mammary epithelium in rabbit. J. Physiol. 253:547-563.

Lollivier, V., P. Lacasse, J. Angulo Arizala, P. Lamberton, S. Wiart, J. Portanguen, R. Bruckmaier, and M. Boutinaud. 2015. In vivo inhibition followed by exogenous supplementation demonstrates galactopoietic effects of prolactin on mammary tissue and milk production in dairy cows. J. Dairy Sci. 98:8775-8787.

Monks, J., and P. M. Henson. 2009. Differentiation of the mammary epithelial cell during involution: Implications for breast cancer. J. Mammary Gland Biol. Neoplasia 14:159-170.

Murthy, G. K., and U. Rhea. 1967. Determination of major cations in milk by atomic absorption spectrophotometry. J. Dairy Sci. 50:313-317.

Oliver, S. P., and L. M. Sordillo. 1989. Approaches to the manipulation of mammary involution. J. Dairy Sci. 72:1647-1664.

Ollier, S., X. Zhao, and P. Lacasse. 2013. Effect of prolactin-release inhibition on milk production and mammary gland involution at drying-off in cows. J. Dairy Sci. 96:335-343.

Ponchon, B., P. Lacasse, N. Silanikove, S. Ollier, and X. Zhao. 2014 Effects of intramammary infusions of casein hydrolysate, ethylene glycol-bis(beta-aminoethyl ether)-N,N, $\mathrm{N}^{\prime}, \mathrm{N}^{\prime}$-tetraacetic acid, and lactose at drying-off on mammary gland involution. J. Dairy Sci. 97:779-788.

Rabot, A., F. Sinowatz, B. Berisha, H. H. Meyer, and D. Schams. 2007. Expression and localization of extracellular matrix-degrading proteinases and their inhibitors in the bovine mammary gland during development, function, and involution. J. Dairy Sci. 90:740-748.

Raulo, S. M., T. Sorsa, T. Tervahartiala, T. Latvanen, E. Pirila, J. Hirvonen, and P. Maisi. 2002. Increase in milk metalloproteinase activity and vascular permeability in bovine endotoxin-induced and naturally occurring Escherichia coli mastitis. Vet. Immunol. Immunopathol. 85:137-145.

Robinson, T. L., I. A. Sutherland, and J. Sutherland. 2007. Validation of candidate bovine reference genes for use with real-time PCR. Vet. Immunol. Immunopathol. 115:160-165.

Singh, K., S. R. Davis, J. M. Dobson, A. J. Molenaar, T. T. Wheeler, C. G. Prosser, V. C. Farr, K. Oden, K. M. Swanson, C. V. Phyn, D. L. Hyndman, T. Wilson, H. V. Henderson, and K. Stelwagen. 2008. cDNA microarray analysis reveals that antioxidant and immune genes are upregulated during involution of the bovine mammary gland. J. Dairy Sci. 91:2236-2246.

Singh, K., J. Dobson, C. V. C. Phyn, S. R. Davis, V. C. Farr, A. J. Molenaar, and K. Stelwagen. 2005. Milk accumulation decreases expression of genes involved in cell-extracellular matrix communication and is associated with induction of apoptosis in the bovine mammary gland. Livest. Prod. Sci. 98:67-78.

Smith, K. L., D. A. Todhunter, and P. S. Schoenberger. 1985. Environmental pathogens and intramammary infection during the dry period. J. Dairy Sci. 68:402-417.

Sorensen, M. T., J. V. Norgaard, P. K. Theil, M. Vestergaard, and K. Sejrsen. 2006. Cell turnover and activity in mammary tissue during lactation and the dry period in dairy cows. J. Dairy Sci 89:4632-4639.

Stelwagen, K., V. C. Farr, H. A. McFadden, C. G. Prosser, and S. R. Davis. 1997. Time course of milk accumulation-induced opening of mammary tight junctions, and blood clearance of milk components. Am. J. Physiol. 273:R379-R386.

Tremblay, G., P. Bernier-Dodier, L. Delbecchi, G. F. Wagner, B. G. Talbot, and P. Lacasse. 2009. Local control of mammary involution: Is stanniocalcin-1 involved? J. Dairy Sci. 92:1998-2006.

Watson, C. J., and P. A. Kreuzaler. 2011. Remodeling mechanisms of the mammary gland during involution. Int. J. Dev. Biol. 55:757762 .

Weaver, S. R., and L. L. Hernandez. 2016. Autocrine-paracrine regulation of the mammary gland. J. Dairy Sci. 99:842-853.

Wilde, C. J., C. V. Addey, P. Li, and D. G. Fernig. 1997. Programmed cell death in bovine mammary tissue during lactation and involution. Exp. Physiol. 82:943-953.

Wilde, C. J., C. H. Knight, and D. J. Flint. 1999. Control of milk secretion and apoptosis during mammary involution. J. Mammary Gland Biol. Neoplasia 4:129-136.

Yart, L., V. Lollivier, L. Finot, J. Dupont, S. Wiart, M. Boutinaud, P. G. Marnet, and F. Dessauge. 2013. Changes in mammary secretory tissue during lactation in ovariectomized dairy cows. Steroids 78:973-981.

Yu, T. C., C. J. Chang, C. H. Ho, H. C. Peh, S. E. Chen, W. B. Liu, H. Y. Peng, P. Piamya, M. T. Chen, and H. Nagahata. 2011. Modifications of the defense and remodeling functionalities of bovine neutrophils inside the mammary gland of milk stasis cows received a commercial dry-cow treatment. Vet. Immunol. Immunopathol. 144:210-219. 